\title{
COVID-19: advance in laboratory diagnostic strategy and technology
}

\author{
Kezhen $\mathrm{Yi}^{1} \cdot$ Yuan Rong ${ }^{1} \cdot$ Cheng Wang ${ }^{2} \cdot$ Lanxiang Huang $^{1} \cdot$ Fubing Wang $^{1} \mathbb{C}$
}

Received: 10 September 2020 / Accepted: 24 November 2020 / Published online: 3 January 2021

(c) Springer Science+Business Media, LLC, part of Springer Nature 2021

\begin{abstract}
SARS-CoV-2 is one of the beta-coronaviruses with the spike protein. It invades host cells by binding to angiotensin converting enzyme 2 (ACE2). This newly discovered virus can result in excessive inflammation and immune pathological damage, as shown by a decreased number of peripheral lymphocytes, increased levels of cytokines, and damages of lung, heart, liver, kidney, and other organs. Effective therapeutic modalities such as new antiviral drugs and vaccines against this emerging virus need to be thoroughly studied and developed. However, so far the only recognized but mild progress in this area is the screening of old drugs for new uses. Therefore, rapid and accurate laboratory SARS-CoV-2 testing approaches are the important basis of identification and blockage of COVID-19 transmission. For COVID-19 patients with different clinical classifications (mild, common, severe, and critically severe), dynamic monitoring of functional indicators of susceptible and vital organs is an important strategy for evaluating therapeutic efficacy and prognosis. In this review, we summarized SARS-CoV-2 laboratory diagnostic schemes, pathophysiological indices of tissues and organs of COVID-19 patients, and laboratory diagnostic strategies for distinct disease stages. Further, we discussed the importance of hierarchical management and dynamic observation in SARS-CoV-2 laboratory diagnostics. We then summed up the advance in SARS-CoV-2 testing technology and described the prospect of intelligent medicine in the prevention of infectious disease outbreaks.
\end{abstract}

Kezhen Yi and Yuan Rong have contributed equally to this work.

Supplementary Information The online version of this article (https://doi.org/10.1007/s11010-020-04004-1) contains supplementary material, which is available to authorized users.

Fubing Wang

wfb20042002@sina.com

1 Department of Laboratory Medicine, Zhongnan Hospital of Wuhan University, No.169 Donghu Road, Wuchang District, Wuhan 430071, People's Republic of China

2 Department of Hand Surgery, Union Hospital, Tongji Medical College, Huazhong University of Science and Technology, Wuhan 430022, China 


\section{Graphic abstract}

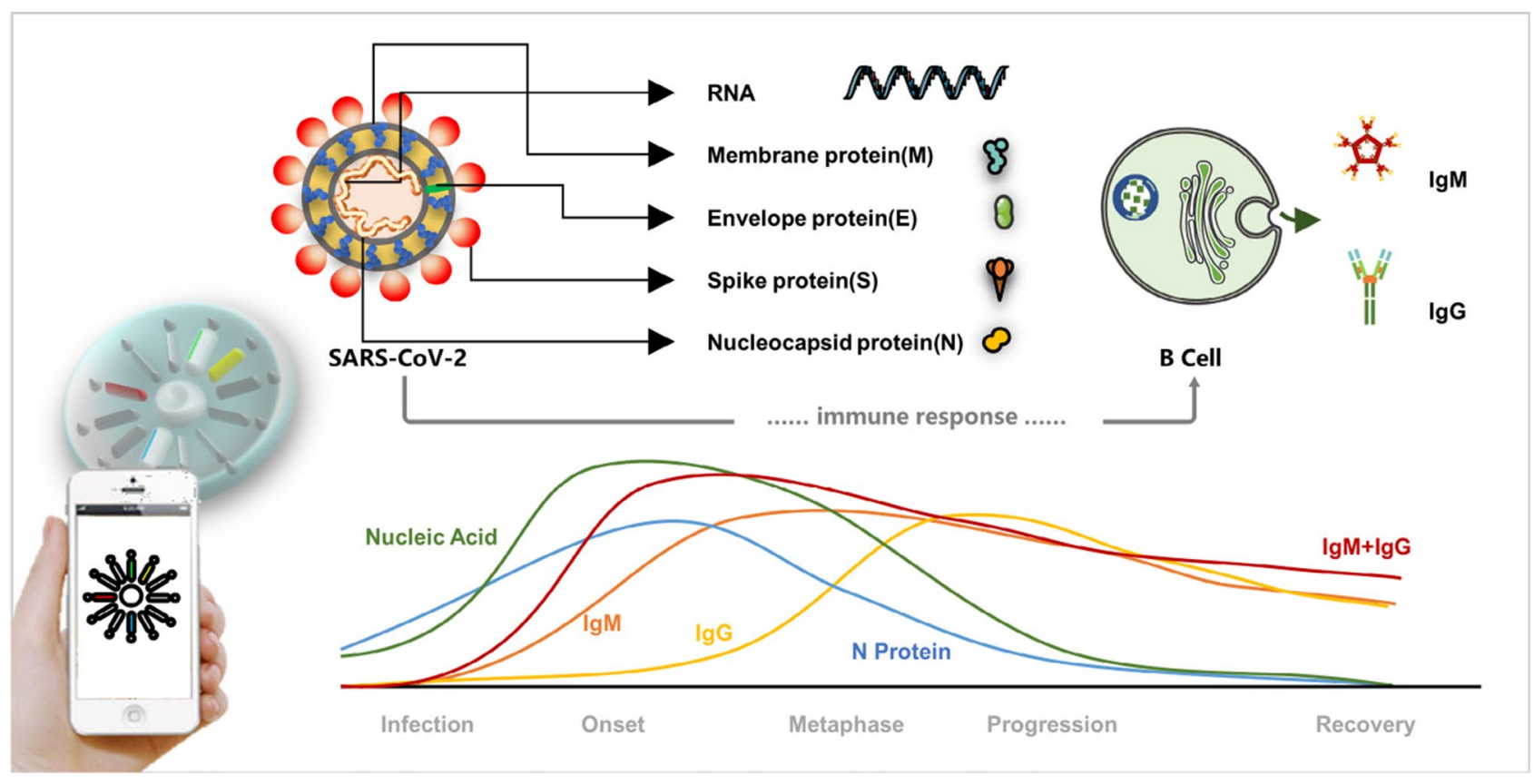

Keywords COVID-19 $\cdot$ SARS-CoV-2 $\cdot$ Laboratory diagnostics $\cdot$ Monitoring indicators

\section{Introduction}

Coronaviruses are segment-free, single-stranded, positivesense RNA viruses. There are six human coronaviruses types, including 229E, nl63, OC43, and hku1 that cause common cold symptoms, SARS CoV causing atypical pneumonia, and MERS CoV causing the Middle East respiratory syndrome [1]. SARS-CoV-2 is a new member of the $\beta$-genus coronaviruses, with a genome size between 26,000 and 32,000 bases containing variable open reading frames (ORFs). Four major SARS-CoV-2 structural proteins are the spike glycoprotein (S), envelope protein (E), membrane protein $(\mathrm{M})$, and nucleocapsid protein $(\mathrm{N})$ [2]. According to the structural analysis of S protein, SARS-CoV-2 has a significant binding affinity to human angiotensin converting enzyme 2 (ACE2) [3]. Single-cell sequencing data revealed that ACE2 is highly expressed in most cell types like type II alveolar epithelial cells, esophageal epithelial cells, and stratified epithelial cells, as well as many tissues and organs such as the heart, kidney, and gastrointestinal tract $[4,5]$. Thus, SARS-CoV-2 not only infect the lung but also other tissues and organs.

Since SARS-CoV-2 may have an impact on all organs and systems throughout the body, management of patients includes early diagnosis and continuous monitoring. The former is specific, including nucleic acid and antibody detection, while the latter is nonspecific. This review discussed the diagnostic information provided by each diagnostic tool and some known shortcomings, and explores how each diagnostic tool complements each other to provide more comprehensive clinical guidance.

In addition, we also report some new technologies that have been applied or have application space in COVID-19, and summarize the types of detection technologies in existing commercial products. Finally, the concept of "intelligent medicine" for infectious epidemics is constructed to provide more possibilities for current or future anti-infectious disease management.

In summary, for the diagnosis of COVID-19, it is necessary to timely identify SARS-CoV-2 infection, and then monitor the functions of susceptible organs in confirmed patients. To prevent and control the COVID-19 pandemic, besides the evolution of high-throughput accurate diagnostic technology in big laboratories, the development of rapid diagnostic techniques in outpatient clinics and regional medical facilities is also important. Intelligent medicine, as an emerging healthcare technology, should also be taken into account for looking for the origin of the COVID-19 pandemic. 


\section{Pathophysiological process and molecular mechanism of SARS-CoV-2 infection}

The basic pathophysiological mechanism of COVID-19 is that SARS-CoV-2 enters target cells via binding to ACE2 on the cell membrane, followed by local or systemic inflammation and immune reactions. According to the results of an autopsy, in addition to the lung, spleen and bone marrow, heart, blood vessels, liver, gallbladder, kidneys, brain, and other organs also suffer pathological changes [6]. For example, the spleen shrinks, and the cardiomyocytes present the signs of degeneration and necrosis (Fig. 1).

After analyzing single-cell RNA sequencing data, Sungnak et al. found that the expression of ACE2 and TMPRSS2 (protease related to virus entry) in goblet cells and ciliary cells of the nasal cavity was high, suggesting that these two cell types in the nasal cavity could be the initial infection sites of SARS-CoV-2 [7]. In the lung, the ACE2 protein mainly exists on the surface of type II alveolar cells and airway club cells. Once SARS-CoV-2 enters the respiratory tract, it replicates, proliferates, and damages the lung regeneration system. According to the report by $\mathrm{Li} \mathrm{Z}$ et al., ACE2 was highly expressed in renal tubular cells, testicular stromal cells, and spermatogenic cells, indicating that SARS-CoV-2 may damage the kidney and the testicular tissue of patients [8]. Also, SARSCoV-2 has been detected in renal tissue samples, indicating that the virus can directly infect human renal tubules and cause acute renal tubule injury [9]. Zhong Nanshan's team isolated SARS-CoV-2 from the urine samples of a patient. The Beijing Ditan hospital confirmed the presence of SARS-CoV-2 in cerebrospinal fluid through gene sequencing. Zhang $\mathrm{H}$ et al. explored the expression of SARS-CoV-2 receptors in different cell types of the digestive tract at the single-cell level, indicating that ACE2 is highly expressed in absorptive epithelial cells and intestinal epithelial cells in the ileum and small intestine [4]. Single-cell RNA sequencing of healthy liver cells of two independent cohorts identified ACE2expression in bile duct cells [10]. However, SARS-CoV-2 can hardly survive in bile, so the liver injury in patients with COVID-19 might be caused by drug toxicity or the systemic inflammatory response. Myocardial injury is more common in severe and critical patients [11-13]. Hence, it is significant to monitor the heart function of COVID-19 patients and treat patients with signs of myocardial injury to prevent

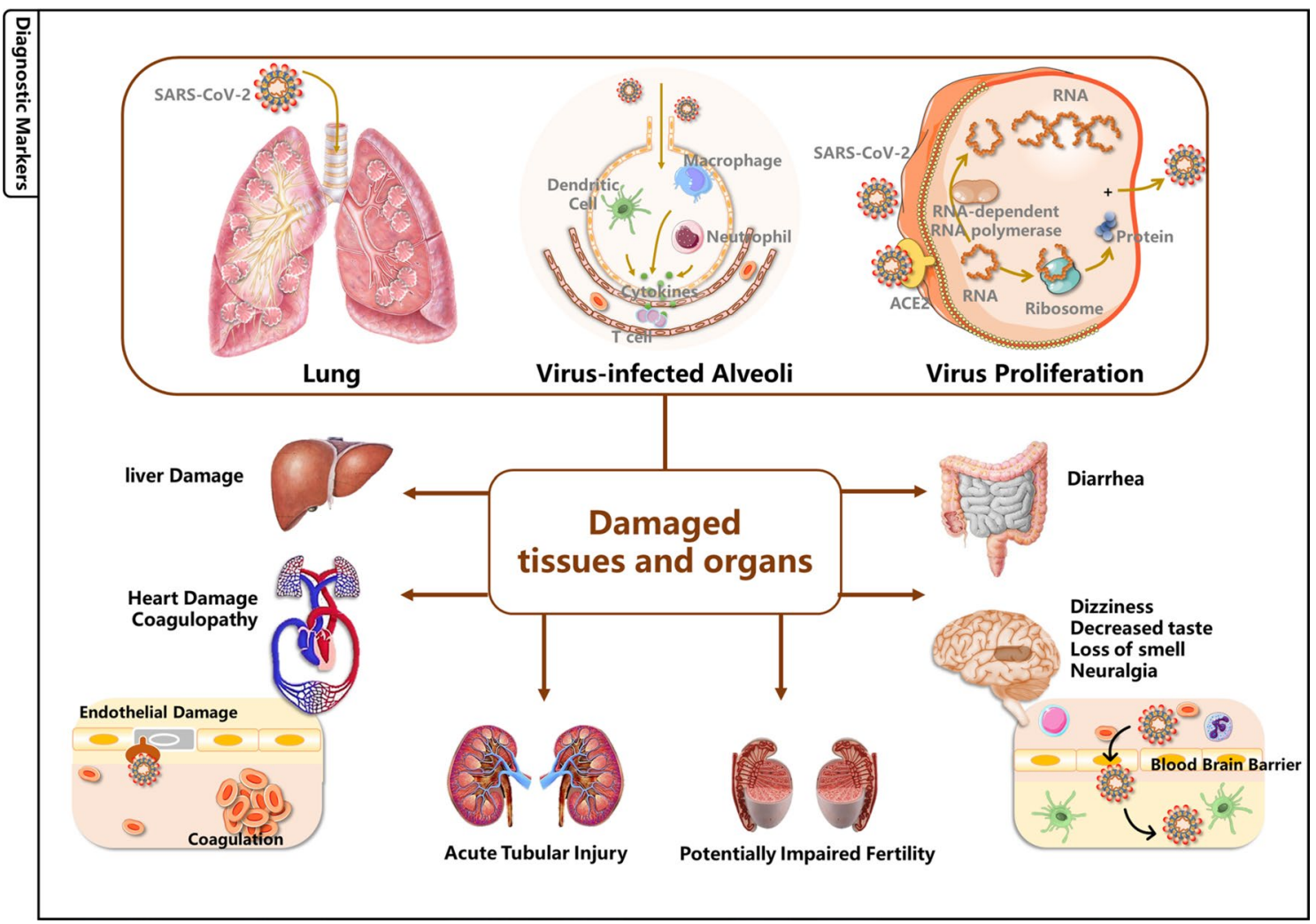

Fig. 1 Schematic illustration of COVID-19 pathophysiology. SARS-CoV-2 causes damage to other tissues and organs in addition to the lung, spleen and bone marrow, heart and blood vessels, liver, gallbladder, kidneys, brain, etc 
heart failure. In addition, some patients' nervous systems are affected [14-16]. 45.4\% of patients with severe symptoms showed neurological alterations, including associated acute cerebrovascular disease, cognitive disorders, and muscle damage [17].

The human body mounts immune responses to viruses, including innate immune response and adaptive humoral/ cellular immune responses. Natural killer cells and mononuclear phagocytes are key players in innate immunity. In humoral immunity, B lymphocytes produce a series of antibodies including neutralizing antibodies that inactivate free viruses. Neutralizing antibodies to the $\mathrm{S}$ protein can block the binding of SARS-CoV-2 to ACE2, thus preventing the entry of the virus into target cells. After neutralizing antibodies binding to the viral surface, an antigen-antibody complex was formed. This complex facilitates the uptake and clearance of viruses by macrophages, and activates the complement system to induce virus degradation. Because SARS-CoV-2 is parasitic in cells, cellular immunity is considered to play a significant role in eliminating SARS-CoV-2. Cellular immunity depends on cytotoxic effector cells, including CD4 + and $\mathrm{CD} 8+$ cytotoxic $\mathrm{T}$ lymphocytes. When recognizing virusinfected cells, cytotoxic effector cells express and release cytotoxic mediators to kill virus-infected cells. An appropriate immune response is helpful for viral clearance, but an over-activated immune system triggers detrimental inflammatory and immune disorders. When excessive cytokines are produced, the permeability of capillary endothelial cells increases, leading to excessive exosmosis of inflammatory cells and plasma, accumulation of superfluous mucus in the alveoli, and even dyspnea. Other tissues and organs can also be damaged, and even multiple organ failure can occur [18-22].

\section{Laboratory diagnostics of COVID-19}

\section{Detection of viral nucleic acids and antiviral antibodies}

Nucleic acid detection is the direct evidence of a viral infection, whereas antibody testing is indirect evidence of a viral infection. The former is considered the "gold standard" for diagnosis. However, its detection efficiency is not high enough due to the problems with the sampling sites and procedures. The latter is the product of antiviral immune response, implicating that the subject has been infected by the virus but not directly indicating the persistence of the virus in the body. Therefore, antibody detection should be used as a supplementary method for nucleic acid detection in laboratory detection of COVID-19 (Fig. 2).

\section{Detection of viral nucleic acids}

Detection of SARS-CoV-2 nucleic acid is the "gold standard" for COVID-19 diagnosis. Existing SARS-CoV-2 testing in clinical laboratories mainly relies on the detection of SARS-CoV-2 nucleic acids after nucleic acid amplification. According to the amplification conditions, the nucleic acid testing techniques are categorized into PCR with thermal cycles and isothermal amplification at a constant temperature.

As a mature technology, PCR is conducted on different detection platforms in distinctive application scenarios. For example, an automatic nucleic acid analysis system is often used in a large medical facility, while a desktop isothermal nucleic acid analyzer is suitable for clinics and urgent care facilities. Portable PCR test strips are especially applicable in point-of-care testing (POCT). Compared to PCR, the isothermal amplification technology can achieve rapid nucleic acid amplification at a constant temperature, thus facilitating quick and on-site testing. For example, the loop-mediated isothermal amplification (LAMP) technology can amplify fragments of target genes at a constant temperature using pre-designed specific primers and the chain-replacement DNA polymerase. However, this technology requires multiple primers, making the primer design principle more stringent than that for RT-PCR.

It has been reported that some COVID-19 patients had false-negative RT-PCR results when CT scans showed significant changes in the lungs and other respiratory infections have been ruled out [23]. This might be due to the following reasons. First, the viral load in various parts of the respiratory tract is different. The main target cells, ACE2-expressing pulmonary epithelial cells, are located in the lower respiratory tract. SARS-CoV-2 is relatively easy to be found in specimens taken at the lower respiratory tract rather than specimens taken at the upper respiratory tract. It has been reported that in the early stage of COVID-19, the positive rate of viral nucleic acid test on sputum samples is higher than that on nose swabs and throat swabs [24]. Zou et al. found that the viral load peaked about 2 days after symptoms appeared and then gradually decreased. Besides, the viral load of the nasal swab was higher than that of the pharyngeal swab [25]. In addition to nasopharynx swabs and bronchoalveolar lavage fluid (BALF), saliva is a sample source for nucleic acid tests. To KK et al. confirmed the expression of ACE2 in the salivary gland, suggesting the possibility of SARS-CoV-2 infecting salivary glands [26]. Further studies confirmed that a large number of SARS-CoV-2 nucleic acids could be detected in saliva [27, 28]. Therefore, the uneven virus distribution in samples of different sources reminds us that a negative test result of a single sample does not mean the virus is absent. The testing needs to be performed on other samples of various sources. In addition, some external 


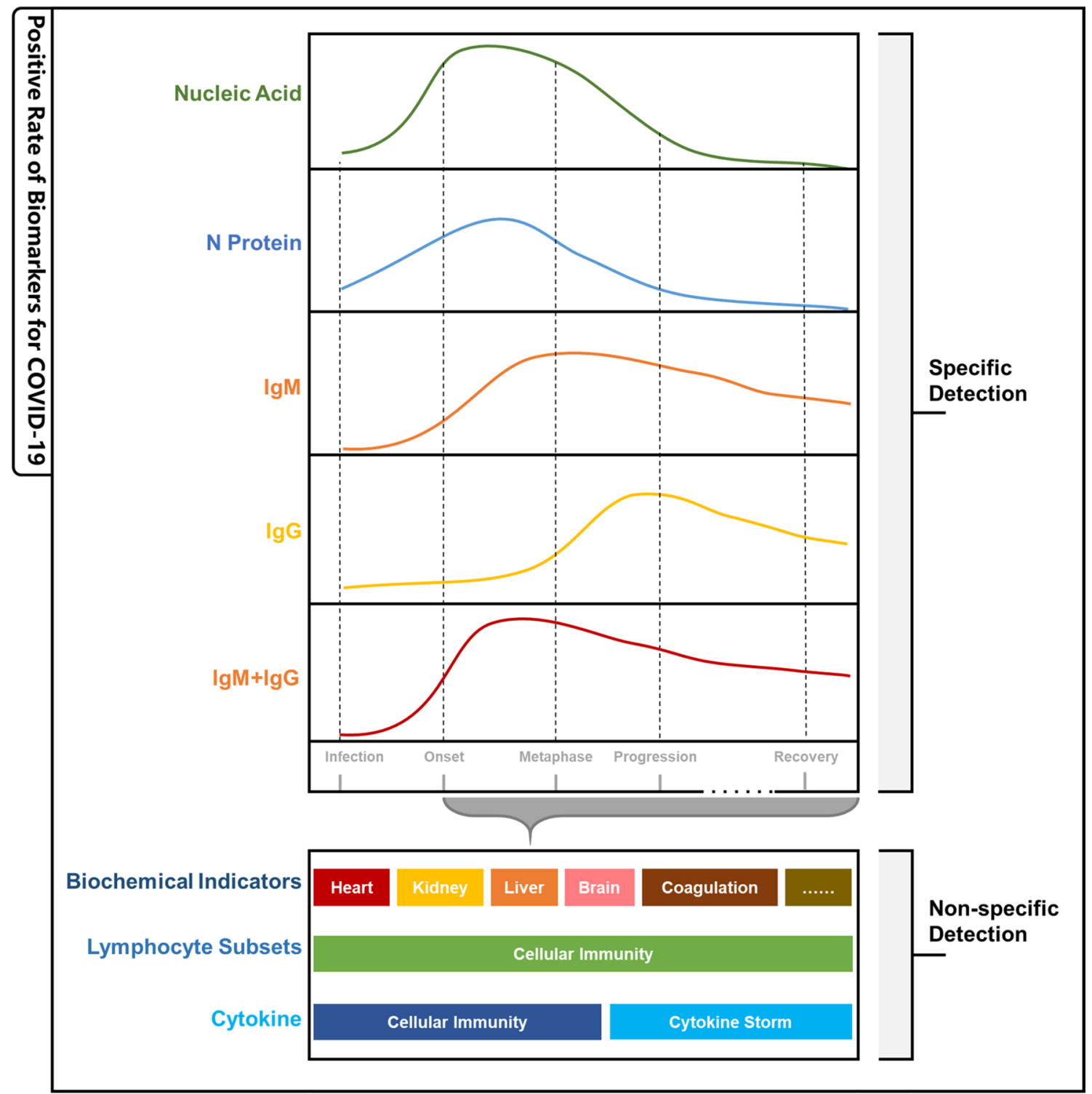

Fig. 2 Changes in the levels of various biomarkers in COVID-19 patients

factors, such as the nucleic acid extraction methods, sample transportation and preservation conditions, the quality of testing reagents, the laboratory environment, and the standardization of sampling, also affect the reliability of nucleic acid testing. Improper sampling or testing procedures may lead to a low positive rate.

\section{Detection of serum IgG and IgM}

Immunological testing of serum biomarkers tells the immune response to human viruses and indirectly detects viral infections. IgG and $\operatorname{IgM}$ are primary antibodies detected in SARS-CoV-2 infection. Generally, IgG is produced relatively late but remains for a longer time. Serum $\mathrm{IgG}$ can be used as a long-term indicator of infection. IgM is produced earlier after infection and plays an important anti-infection role in the early stage of infection. However, it only lasts for a short time and disappears quickly. After the onset of COVID-19, the overall positive rate of IgG and IgM to SARS-CoV-2 increases gradually. The longer the time from the disease onset, the higher the positive rate of IgG and IgM in the test. 17-20 days after the disease onset, the $\mathrm{IgG}$ positive rate reaches $100 \%$, while the IgM-positive rate reaches $94.1 \% 20-22$ days after the disease onset. The median time of $\mathrm{IgG}$ and IgM seroconversion is 13 days after the disease onset, but only $70.7 \%$ of the patients can be diagnosed according to the dynamic change of antibody titer [29]. Studies found that the median time of serum transformation of antibody was about 2 weeks [30, 31]. Compared with the total antibody, the sensitivity of IgM alone, 
$\operatorname{IgG}$ alone, and a simple combination of $\operatorname{IgM}$ and $\operatorname{IgG}$ in the diagnosis of COVID-19 was lower than that of total antibody [32]. In the above studies, a small number of confirmed cases were always antibody-negative during the observation period. Moreover, antibody detection is insufficient to distinguish existing and previous infections. Hence, serological antibody detection should be considered as a supplementary to viral nucleic acid detection [33]. Common antibody detection techniques include the fully automated chemical luminescence immunoassay system and immunotomography technology. The automatic chemical luminescent immunoassay systems can automate high-throughput quantification of blood antibodies, making it ideal for large medical centers. The colloidal gold immunotomography is simple, practical, and adaptable, but it can only generate qualitative results. After the outbreak, a variety of new detection technologies emerged, such as LAMP, digital PCR, CRISPR, and single molecule detection. But what really plays a greater role in clinical application is the traditional technology: PCR and immunoassay (Figure S1). Therefore, in this review, details on new technologies are presented in the section entitled "Development of SARS-CoV-2 detection technology".

Nucleic acid detection and antibody detection complement each other. A combination of the two approaches is expected to facilitate the diagnosis of COVID-19 (Fig. 3).

\section{Dynamic monitoring of COVID-19 patients}

To take care of COVID-19 patients, dynamic monitoring of the nonspecific indices should be performed to evaluate disease progression especially the functions of vital organs and tissues (Table 1).

\section{Early warning signs of disease progression}

\section{Underlying health conditions}

Underlying health conditions affects the prognosis of COVID-19 patients. The most common underlying health conditions are hypertension, diabetes, cardiovascular diseases, and chronic obstructive pulmonary disease. Zhou $\mathrm{F}$ et al. found that patients who died of COVID-19 (average age 69) are older than survivors (average age 52) [38]. Another study suggested that patients older than 50 are at medium and high risk [39]. Having more than one underlying condition also leads to poor prognosis. Guan $\mathrm{W}-\mathrm{j}$ et al. found that about a quarter of Chinese COVID-19 patients had comorbidities and were prone to have poor clinical outcomes [40]. Among them, cancer and chronic obstructive pulmonary disease incur the greatest risk of poor prognosis. In addition, compared with patients without basic diseases, having a single underlying health condition raises the risk of poor prognosis by about $79 \%$. Having two or more underlying health conditions increases the risk of poor prognosis by 1.59 folds. In previous studies, hypertension or diabetes significantly slowed down the rate of SARS-CoV-2 clearance, increased patients' susceptibility to multiple organ disorders and secondary infections, and consequently caused poor prognosis and higher mortality [41-44]. Cancer patients are reported to have a higher risk of SARS-CoV-2 infection and a higher rate of severe illness, and they deteriorate faster than others [45, 46].

\section{Peripheral blood biomarkers}

The change in peripheral blood biomarkers is one of the important clinical manifestations of patients with COVID19. Combined with the immune system indicators, the blood biomarkers can illustrate clinical outcomes. Blood indices mainly include the parameters of blood components, liver and kidney functions, myocardial function, coagulation function, etc. In addition, some indices can directly reflect SARS-CoV-2 infection. Zhang B et al. found that the higher the neutrophil-lymphocyte ratio (NLR), the more severe the COVID-19 condition was. Patients who died of COVID-19 often showed a high NLR ratio [47]. Wan $S$ et al. also found that the proportions of CD4 $+\mathrm{T}$ cells and CD8 $+\mathrm{T}$ cells in severe patients were significantly higher, suggesting that $\mathrm{T}$ cells were more susceptible to functional exhaustion in severe patients [48]. Moreover, studies found that IL-6 is the key inflammatory factor for the cytokine storm in COVID-19 patients $[13,48]$. Therefore, the IL-6 assessment is supposed to be increased to predict the severity of COVID- 19 .

\section{Screening of other respiratory viruses}

During isolating and treating confirmed COVID-19 cases, it is necessary to screen other respiratory viruses at hospital admission to prevent cross-infection. The screening tells the presence or absence of other respiratory viruses with high incidence in autumn and winter, and subsequently distinguishes COVID-19 from other viral infections with similar symptoms. Previous data showed that nearly $6 \%$ of COVID19 close contacts in Wuhan were infected with SARS-CoV-2 while $18 \%$ of them were free of SARS-CoV-2 infection but infected with other respiratory pathogens [49]. Therefore, it is worth conducting the screening to avoid high crossinfection risk of COVID-19 in hospitals.

\section{Dynamic monitoring of mild and common cases}

The purpose of monitoring mild cases is to shift patients to other healthcare facilities when their conditions are aggravated, and to save healthcare resources for patients in severe or critical conditions [50,51]. Viral load and functions of 


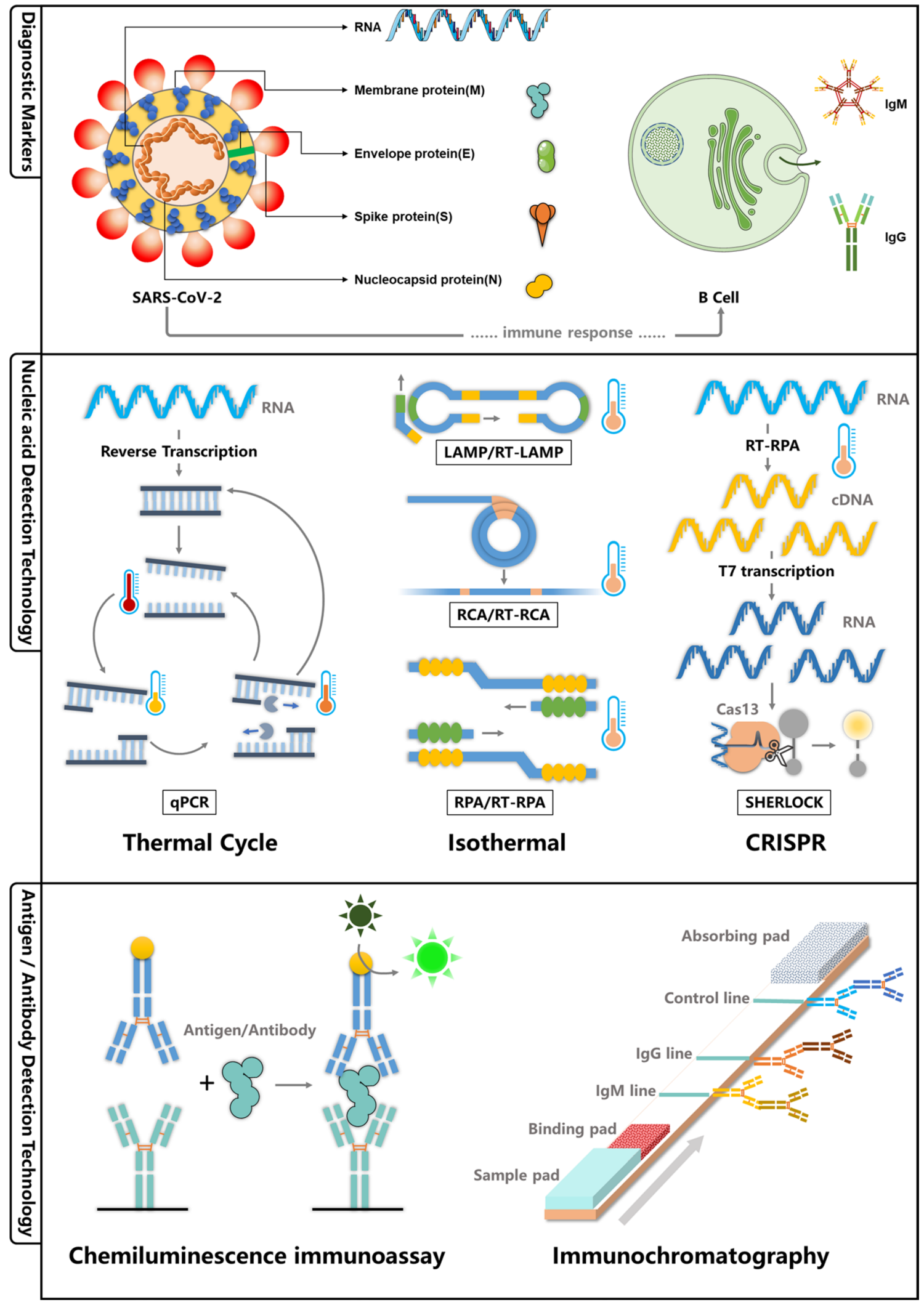

Fig. 3 Specific biomarkers for SARS-CoV-2 detection include pathogenic markers and serological markers. The former are viral nucleic acids and proteins, and the latter are specific antibodies produced by the immune system. The nucleic acid detection technology involves thermal cycle amplification and isothermal amplification. The mainstream technologies for antigen and antibody detection are chemiluminescent immunoassay and immunochromatography 
Table 1 Biomarkers for monitoring tissues and organs in patients with COVID-19

\begin{tabular}{|c|c|c|c|}
\hline Organ or system & Monitoring indicators & Clinical manifestations & References \\
\hline Heart & $\begin{array}{l}\text { - Myocardial zymogram } \\
\text { - Myoglobin } \\
\text { - Troponin }\end{array}$ & $\begin{array}{l}\text { - Increased lactate dehydrogenase, myozyme } \\
\text { and myoglobin in some patients, and } \\
\text { increased troponin in some critically ill } \\
\text { patients }\end{array}$ & [13] \\
\hline Liver & $\begin{array}{l}\text { - Alanine aminotransferase } \\
\text { - Aspartate aminotransferase } \\
\text { - Total protein } \\
\text { - Albumin/ } \\
\text { - Globulin } \\
\text { - Albumin/globulin } \\
\text { - Total bilirubin }\end{array}$ & $\begin{array}{l}\text { - Some patients may have increased liver } \\
\text { enzymes }\end{array}$ & {$[34]$} \\
\hline Kidney & $\begin{array}{l}\text { - Blood creatinine } \\
\text { - Blood urea } \\
\text { - Blood uric acid }\end{array}$ & $\begin{array}{l}\text { Blood urea and blood creatinine levels in } \\
\text { critically ill patients are rapidly increasing }\end{array}$ & {$[9,35]$} \\
\hline Lung ventilation function & - Blood gas analysis & $\begin{array}{l}\text { - Pao2 decreased significantly in critically ill } \\
\text { patients with hypoxemia } \\
\text { - One of the clinical classification indexes of } \\
\text { severe patients }\end{array}$ & {$[35]$} \\
\hline Coagulation & $\begin{array}{l}\text { - Platelets } \\
\text { - D-dimer(D-D) } \\
\text { - Fibrin degradation products (FDP) } \\
\text { - Prothrombin time (PT) } \\
\text { - Activated partial thromboplastin time (APTT) }\end{array}$ & $\begin{array}{l}\text { - Abnormal blood coagulation, especially } \\
\text { D-dimer and FDP is significantly increased, is } \\
\text { very common in non-survivors of COVID-19 }\end{array}$ & {$[34,35]$} \\
\hline Immune function & $\begin{array}{l}\text { - C-reactive protein (CRP) } \\
\text { - Serum amyloid A(SAA) } \\
\text { - Procalcitonin (PCT) } \\
\text { - Neutrophil/lymphocyte ratio (NLR) } \\
\text { - Cytokines }\end{array}$ & $\begin{array}{l}\text { - Most patients have elevated c-reactive protein } \\
\text { - SAA results increased significantly early in } \\
\text { the infection } \\
\text { - Most patients have normal procalcitonin } \\
\text { (assist the identification of bacterial and viral } \\
\text { infections) } \\
\text { - Neutrophil/lymphocyte ratio (NLR) helps } \\
\text { predict disease progression } \\
\text { - The number of CD4 + and CD8 + T cells in } \\
\text { peripheral blood is greatly reduced, while the } \\
\text { state is over-activated } \\
\text { - Severe and critically ill patients often have } \\
\text { elevated cytokines }\end{array}$ & {$[6,13,34,36,37]$} \\
\hline
\end{tabular}

vital organs and systems should be closely monitored. Zheng $\mathrm{Y}$ et al. suggests that organ damage in mild cases might not be the result of inflammation but the virus itself [52]. Therefore, the dynamic monitoring of viral load tells the extent of viral clearance and therapeutic efficacy. Because cellular immunity is the major mechanism fighting SARS-CoV-2, the quantities and activities of lymphocyte populations largely reflect the extent of immune mobilization against the virus. Other crucial biochemical indices include blood components, urine components, liver and kidney functions, creatine kinase, myoglobin, coagulation system components, C-reactive protein, and others.

\section{Dynamic monitoring of severe and critical cases}

For severe patients, the dynamic monitoring of the immune system function and inflammatory response is also necessary to prevent condition deterioration. Since cellular immunity plays a major role in viral clearance, and CD4+ and CD8+T cells are the key players in cellular immunity, monitoring lymphocyte populations is crucial for prognosis evaluation. Immune cells such as CTLs, macrophages, and NK cells recognize virus-infected cells and then release cytokines to kill target cells. But when cytokine production loses control, the increase of permeability of capillary endothelial cells causes excessive exosmosis of inflammatory cells and plasma, and then leads to mucus accumulation in the alveoli and even dyspnea. In particular, a surge of cytokines in a COVID-19 patient results in a cytokine storm in which IL-2, IL-7, IL-10, GSCF, IP-10, MCP1, MIP1A, and TNF- $\alpha$ are all involved. The cytokine storm destroys the function of the heart, kidney, liver, and other organs. The cytokine storm is more frequently seen in severe COVID-19 patients rather than mild patients, and IL-6 is the key player [36]. In conclusion, lymphocytes and cytokines are related to the severity 
of the disease. Monitoring of lymphocytes and cytokines helps establish a model of COVID-19 severity prediction.

For critical cases, dynamic monitoring of lactate, electrolyte, myocardial indices (such as troponin, B-type natriuretic peptide, or B-type natriuretic peptide pro-n-terminal peptide), coagulation function, and other parameters should be performed. These biochemical indicators reflect the functions and damage of non-pulmonary organs, and predict the risk of death for critical cases. Besides, Extracorporeal Membrane Oxygenation (ECMO) is one of the core support systems for severe respiratory failure. Common complications of ECMO include limb ischemia and necrosis, hemorrhage, infections, thrombosis, and hemolysis at the intubation side. Monitor of coagulation function should be carried out on patients undergoing ECMO.

The hierarchical control should be addressed to confine the COVID-19 epidemic. The principle of hierarchical control is that subjects are grouped, tested, and diagnosed by selected detection techniques and methods according to different testing scenarios. In this manner, a scalable and cost-efficient system for optimizing testing and patient distribution can be established to save medical resources (Fig. 4).

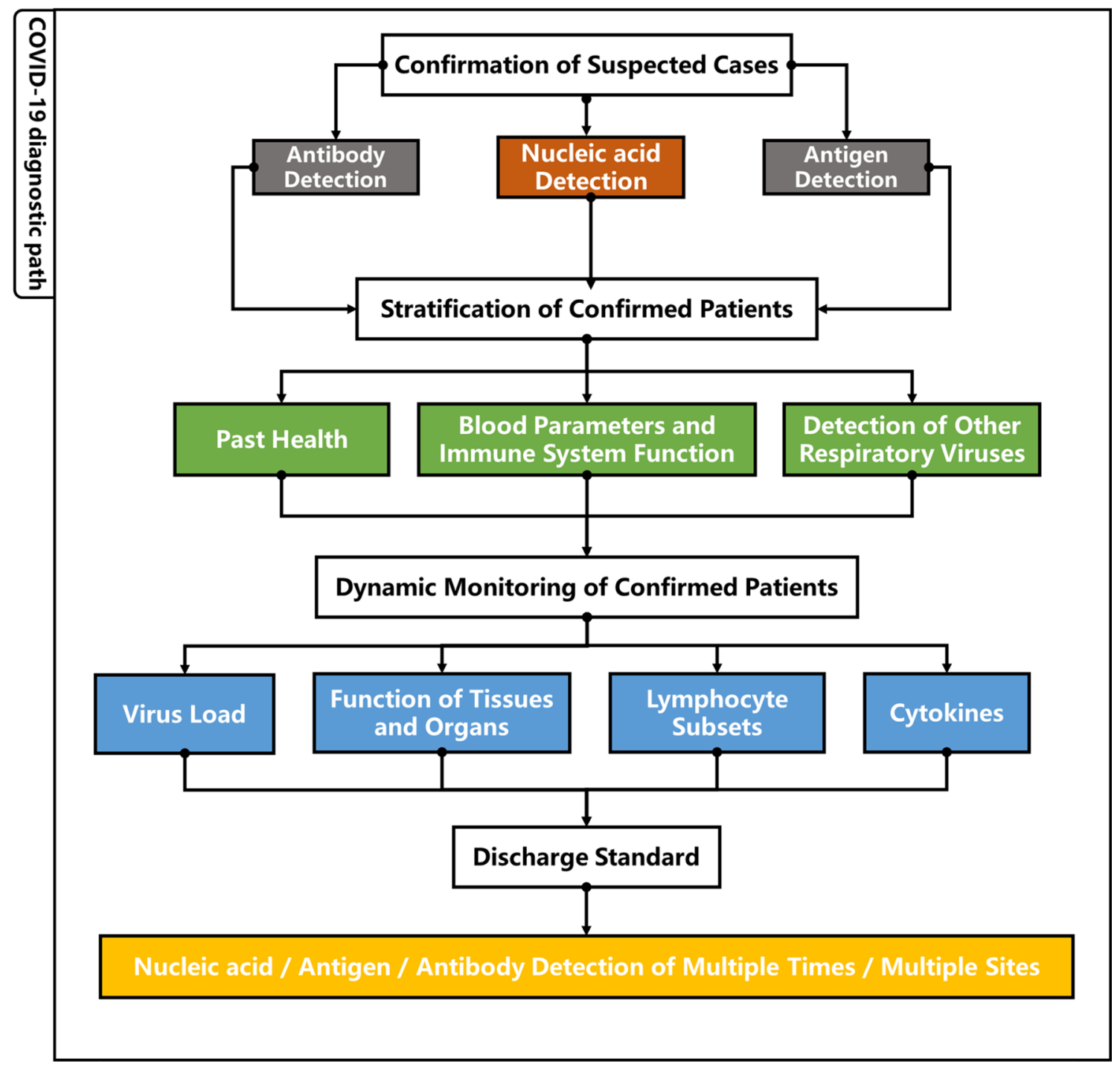

Fig. 4 Laboratory diagnostic path of COVID-19. The laboratory diagnostic path of COVID-19 includes the confirmation of suspected cases, the stratification of confirmed patients, dynamic monitoring of admitted patients, and discharge diagnosis of cured patients. The "gold standard" for the diagnosis of suspected cases is nucleic acid detection, and the results of antigen and antibody tests are used as an aid 


\section{Dynamic monitoring of discharged patients and virus variation}

The discharge criteria in The New Coronavirus Pneumonia Diagnosis and Treatment Program (Trial Version 7) are: (1) the body temperature returns to the normal level for more than 3 days; (2) significant improvement in respiratory symptoms; (3) pulmonary imaging shows significant improvement in acute osteopathy; (4) two consecutive nucleic acid tests on the respiratory specimen (at least 1 day apart) are negative. However, it is reported that nucleic acid tests turned positive in many discharged patients. SARSCoV-2 has also been isolated from fecal and urine samples. A retrospective cohort study found that the duration of SARS-CoV-2 in fecal samples was significantly longer than that in respiratory and serum samples, highlighting the possibility of fecal transmission of the virus. It is, therefore, necessary to strengthen the management of fecal samples to prevent and control the spread of COVID-19 [53]. These findings suggest that it is necessary to adjust the laboratory tests in the discharge diagnosis, such as increasing sample types, increasing the sampling frequency, and prolonging the observation period before discharge or the isolation period after discharge.

In addition to setting strict control of discharge, healthcare agencies should also be alert to critical SARS-CoV-2 mutations. To understand the dynamic change of the SARS$\mathrm{CoV}-2$ genome, it is necessary to collect and sequence SARS-CoV-2 at different time points and different geological locations. Gene sequencing is currently the only method to dynamically track viral mutations. Nano-hole targeted sequencing (NTS) covers all important virulence-associated genes in the viral genome, and therefore detects mutations in virulence-associated genes to assist in COVID-19 prevention and control [54].

\section{Development of SARS-CoV-2 detection technology}

New SARS-CoV-2 testing techniques mainly derive from existing molecular diagnostics technologies, including LAMP, digital PCR, CRISPR, and single molecule detection. Compared with RT-PCR, digital PCR is more sensitive and able to measure the absolute number of molecules of interest. It eliminates the bias caused by differential amplification efficiency which is the problem with fluorescencebased quantitative PCR. However, although various microfluidic chip-based digital PCR techniques have substantially facilitated virus testing, they still rely on thermal cycling. The need for precise temperature cycling makes digital PCR only applicable in central laboratories. A novel quick and safe POCT technique for coronavirus nucleic acid detection is in urgent demand. Zhang Feng et al. developed a CRISPRbased SHERLOCK (Specific High Sensitivity Enzymatic Reporter UnLOCKing) technique for SARS-CoV-2 detection. The principle of this technique is that the endonuclease cas 13 forms a detection complex with the complementary leading RNA sequence of the viral nucleic acid. When viral RNA is recognized by cas 13 , cas 13 is activated and subsequently cut off viral RNA to activate fluorescein. The whole testing process is easy and quick, and the result is shown directly on provided test strips. Besides the direct detection of viral nucleic acids, viral antigens can also be tested. Generally, specimen collected at infection sites such as throat swabs are used in viral antigen testing. However, we require new antigen testing techniques with higher sensitivity, because the virus quantity in ordinary specimens is usually too low to be detected in early diagnosis. SMC ${ }^{\text {TM }}$ is a single molecule counting technology with ultra-high sensitivity. It can detect low-abundance biomarkers at $\mathrm{fg} /$ $\mathrm{mL}$ levels in complex biological matrices. SMC ${ }^{\mathrm{TM}}$ technology is based on the traditional double-antibody sandwich ELISA. After elution, the fluorescein-labeled detection antibody is dissociated from the immune complex and the fluorescein is sensed by the single molecule detection system. The fluorescent signals are recorded one by one and calculated synchronously. Additionally, Quanterex technology developed a digital ELISA which is similar to digital PCR. The main difference between the digital ELISA and traditional immunoassay is that the former can capture single immunocomplexes on paramagnetic beads in arrays of femtoliter-sized wells. These highly sensitive and specific POCT techniques are very important in the early diagnosis of COVID-19. They can not only relieve the pressure of large hospitals in the early stage of the pandemic but also assist in the identification of asymptomatic COVID-19 cases after reopening economy. Therefore, the microfluidic chip acts as a "micro version" laboratory and plays an important role in SARS-CoV-2 detection [55]. In the diagnosis of Ebola, some research institutions developed a simple bioassay protocol using microfluidic devices featuring integrated photoelectric signal transduction. In this protocol, a silica bead-based microfluidic device captures and detects the products of rolling circle amplification (RCA) at femtomolar levels. To detect multiple pathogens, a multiple LAMP assay can identify a wide range of pathogens after the optimization of reaction conditions. Some researchers also developed nanopore targeted sequencing (NTS) to detect SARS-CoV-2 as well as 10 families and 40 types of respiratory viruses. The detection threshold of NTS is 100 times higher than that of qPCR [54]. In addition, LAMP has also been upgraded by digital technology. Digital LAMP (dLAMP) can be used to determine the nucleic acid concentration in a single test. It reduces labor intensity and instrument complexity in virus testing. Rodriguez-Manzano J et al. developed the on-chip 
loop-mediated DNA amplification, which allows smartphones to record and analyze the results [56]. Therefore, the simultaneous detection of viral nucleic acids and antibodies via the combination of smartphones and digital isothermal microfluidic detection becomes the trend in SARS-CoV-2 detection techniques [31].

Measurements of cell subsets or cytokines are primarily performed by flow cytometry and fluorescent labeling. Spillover cross-interference of various fluorescent signals in the detection of multiple molecules is always a concern. To solve this problem, diverse coding methods have been applied to optimize the simultaneous identification of multiple biomarkers in different diseases. This would lead to the establishment of the COVID-19 cytokine spectrum shortly. Liu B et al. have used surface-enhanced Raman scattering (SERS) nanotags to assess distinct protein markers on a single anti-opal photonic crystal microsphere. According to their report, this approach features high sensitivity, a wide linear dynamic range, and easy information collection for multiple biomarkers by a single Raman spectrum acquisition [57]. In addition, Applied Biocode company has developed a new generation of digital liquid-phase chip which uses digitally barcoded magnetic beads to specifically identify biomarkers. Merck launched the MILLIPLEX ${ }^{\circledR}$ Multiplex Assay system powered by Luminex ${ }^{\circledR}$ xMAP® technology. The MILLIPLEX system is based on color-coded polystyrene beads. Bead coloration is achieved by utilizing different concentrations of red and infrared fluorophore dyes to create dozens of uniquely colored bead sets. These bead sets are then combined within the same assay well. Each analyte is distinguished from the other because they are bound to differently colored/fluorescent beads. The high-throughput detection techniques can facilitate the simultaneous detection of a wide spectrum of cytokines.

In short, the development of SARS-CoV-2 detection technology may fulfill the easier, faster, and more accurate diagnosis of COVID-19 (Fig. 5). However, whether the new technology can truly replace the traditional pathogen diagnosis technology still needs a long period of practice. As can be seen in Table 1 and Figure S1, nucleic acids and antibodies are the mainstays in the detection of COVID-19 today. Nucleic acid detection mainly relies on qPCR, and antibody detection mainly relies on labeled immunoassays (such as enzyme-linked immunoassay, radiation Immunoassays, fluorescent immunoassays, luminescence immunoassays, etc.), while emerging technologies utilized in clinical diagnostics account for a very small share. Emerging diagnostic technologies often face the following problems in clinical diagnosis: (1) Some products are miniaturized for convenience and speed, but this often results in lower throughput; (2) Some technologies have not yet been completed Large samples are tested, so the test results are often unstable; (3) Some technologies have not yet developed a mature supporting equipment market, or require very sophisticated or expensive instruments. For example, Abbott ID NOW received widespread attention in the early days of its release, but many recent documents question its accuracy $[22,58]$.

- https://www.nmpa.gov.cn/(click this website for information about detection technology from NMPA in Table 2).

- https://www.fda.gov/medical-devices/coronavirus-disea se-2019-covid-19-emergency-use-authorizations-medic al-devices/vitro-diagnostics-euas(click this website for information about detection technology from FDA in Table 2).

- https://covid-19-diagnostics.jrc.ec.europa.eu/devic es(click this website for information about detection technology from EU in Table 2).

\section{Conclusions}

COVID-19 has different clinical characteristics at different stages, requiring specific diagnostics to determine the disease progression. Before hospital admission, a hierarchical diagnosis strategy should be carried out and a sensitive diagnostic technology must be applied to implement early diagnosis. After admission, the disease progression and host immune response should be dynamically monitored to evaluate the severity of the disease. Before discharge, the therapeutic efficacy needs to be determined. The detection parameters must be carefully set. Viral nucleic acids, viral antigens, antiviral antibodies, lymphocyte populations, and cytokines serve different monitoring purposes. With the development of detection techniques, COVID-19 tests can now be carried out in central laboratories, clinics, pharmacy stores, and roadside" testing booths [59-68] (Table 3).

It has been suggested that asymptomatic COVID-19 patients and patients with mild symptoms can transmit SARS-CoV-2. If they are not isolated on time, the risk of community transmission of COVID-19 will rise, and the public will be in danger. The development and application of RT-PCR-based viral nucleic acid testing reagents have played a significant role in the screening and diagnosis of COVID-19 patients. However, RT-PCR testing is conducted in centralized facilities in a time-and-labor consuming manner, and the detection rate of viral nucleic acids by RT-PCR is somehow disappointing. Therefore, it is necessary to upgrade the diagnostics for asymptomatic patients. Given the lack of therapies such as the COVID-19 vaccine, the current focus remains on monitoring the source of infection. Artificial intelligence and deep learning can improve the detection and diagnosis ability of COVID-19 [69-71]. Big data analysis are a modeling study of viral activity that can predict the size, dynamics of outbreaks 


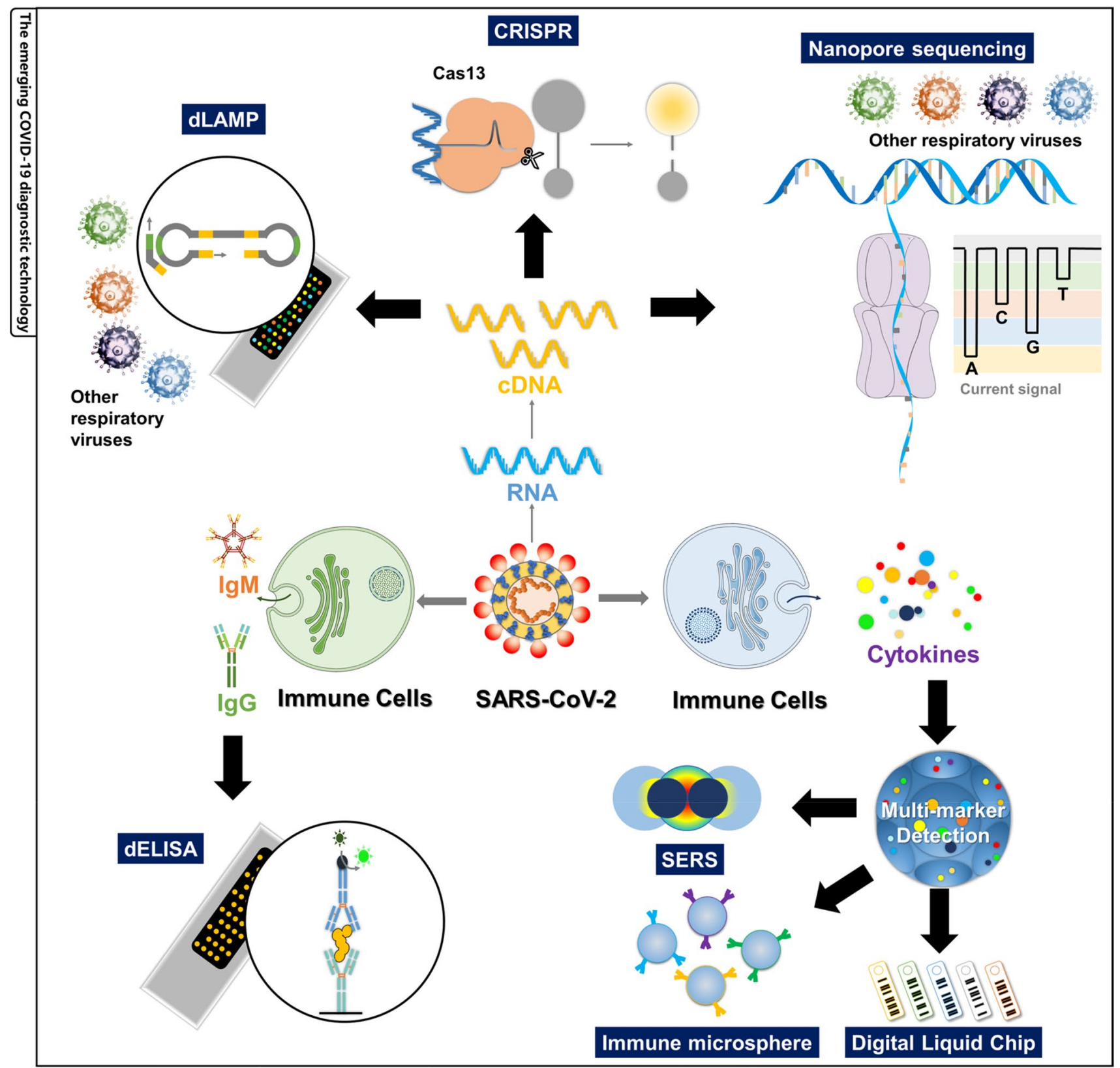

Fig. 5 The emerging COVID-19 diagnostic technology. Dropletbased microfluidics accelerates the speed and promotes the accuracy of SARS-CoV-2 nucleic acid detection and antibody detection. The

and the preventive measures that should be taken, thus providing more comprehensive recommendations for decision-makers [72-74]. The Internet of Things (LoT) provides a platform for public health agencies to access data to monitor the COVID-19 pandemic, such as daily reports issued by the World Health Organization [75]. The role of mobile health applications is mainly to collect data and distribute information [73]. The former includes the upload of diagnostic results, the recording of health data of wearing devices, the recording of moving tracks, etc., new trend in cytokine measurement is to evaluate a wide spectrum of cytokines, using SERS, immune microspheres, and digital liquid chips alone or together

while the latter includes health pass codes, the location of confirmed or suspected cases in nearby areas, and relevant news on social media. But there are obstacles in practical application, including doubts about the reliability of nonclinical laboratory data, inadequate privacy protection of users, and the audience limitations of smartphones and false information in numerous social software. With the rapid advance of molecular testing technology and intelligent technology, it is feasible to establish a smartphonefriendly Cloud-based rapid diagnosis platform to empower 
Table 2 Emerging detection technology of COVID-19 in NMPA/FDA/EU

\begin{tabular}{|c|c|}
\hline Emerging detection technology in NMPA/FDA/EU & Examples \\
\hline \multicolumn{2}{|l|}{ NMPA } \\
\hline Quantum dot fluorescence immunochromatography & $\begin{array}{l}\text { Novel coronavirus (2019-nCoV) IgM/IgG antibody detection kit } \\
\text { (Shanghai Kexin Biotechnology Co., Ltd.) }\end{array}$ \\
\hline Upon version luminescence immunochromatography & $\begin{array}{l}\text { Novel coronavirus (2019-nCoV) antibody detection kit (Beijing Hotgen } \\
\text { Biotech Co., Ltd.) }\end{array}$ \\
\hline Isothermal amplification nucleic acid detection & $\begin{array}{l}\text { CapitalBio respiratory virus nucleic acid detection Ki (CapitalBio } \\
\text { Technology Inc.) }\end{array}$ \\
\hline Combined probe-anchored polymerization sequencing & $\begin{array}{l}\text { Novel coronavirus 2019-ECoV nucleic acid detection kit (Beijing } \\
\text { Genomics institution) }\end{array}$ \\
\hline RNA capture probe method & $\begin{array}{l}\text { Novel coronavirus 2019-nCoV nucleic acid detection kit (Shanghai } \\
\text { Rendu Biotechnology Co., Ltd.) }\end{array}$ \\
\hline Hybrid capture immunofluorescence & $\begin{array}{l}\text { Novel coronavirus 2019-ECoV nucleic acid detection kit (Anbio (Xia- } \\
\text { men) Biotechnology Co., Ltd.) }\end{array}$ \\
\hline \multicolumn{2}{|l|}{ FDA } \\
\hline droplet digital PCR & Bio-Rad SARS-CoV-2 ddPCR Test (Bo-Rad Laboratories, lnc.) \\
\hline Isothermal amplification nucleic acid detection & ID now covID-19 (Abbott Diagnostics Scarborough, Inc.) \\
\hline In vitro diagnostic (IVD) workflow for gene sequencing & Illumina COVIDSeq test (Illumina, Inc.) \\
\hline Saliva nucleic acid detection & $\begin{array}{l}\text { Rutgers clinical genomics laboratory TaqPath SARS-CoV-2-assay } \\
\text { (Illumina, Inc.) }\end{array}$ \\
\hline CRISPR & $\begin{array}{l}\text { SARS-CoV-2 RNA DETECTR assay (UCSF Heath Clinical Laborato- } \\
\text { ries, UCSF clinical Labs at China Basin) }\end{array}$ \\
\hline \multicolumn{2}{|l|}{ EU- CE } \\
\hline Pathogen Metagenomics (mNGS) & SARS-Cov-2 Clinical sequencing assay (Vision Medicals) \\
\hline Proteome microarray & $\begin{array}{l}\text { PEPperPRINT GmbH PEPperCHIPE@SARS-CoV-2 proteome micro- } \\
\text { array (PEPperPRINT GmbH) }\end{array}$ \\
\hline \multicolumn{2}{|l|}{ EU- no CE } \\
\hline Tongue swab diagnosis of SARS-Cov-2 & Tongue swab diagnosis of SARS-CoV-2(University of Washington) \\
\hline $\begin{array}{l}\text { Electrical detection of SARS-CoV-2 nucleocapsid protein using nano } \\
\text { sensors and aptamer }\end{array}$ & Pinpoint Coid-19 screening assay (Pinpoint Science Inc.) \\
\hline $\begin{array}{l}\text { Microarray based high-throughput elisa-like coVID-19 IgG/IgM/IgA } \\
\text { assay }\end{array}$ & $\begin{array}{l}\text { pGOLD }{ }^{\mathrm{TM}} \text { COVID-19 high accuracy IgG/lgM assay kits (Nirmidas } \\
\text { Biotech Inc.) }\end{array}$ \\
\hline Exhaled volatile organic compounds (VOC) as virus biomarkers & Airostotlecv1s (Canary Health Technologies) \\
\hline Detection of innate immune response cell activation in the blood & Ativa enhanced screen (Ativa Medical) \\
\hline
\end{tabular}

Table 3 Comparison of diagnostic methods for the detection of SARS-CoV-2

\begin{tabular}{lllllll}
\hline Method & Target & Sample type & $\begin{array}{l}\text { Clinical sensi- } \\
\text { tivity (\%) }\end{array}$ & Specificity (\%) & Test time (min) & References \\
\hline RT-PCR & Virus mRNA & Respiratory swabs, saliva, sputum, BLF & $30-67.1 \%$ & 100 & $120-140$ & {$[59,60]$} \\
CRISPR & Virus mRNA & Respiratory swabs, saliva & $95-100$ & 100 & $45-70$ & {$[61-63]$} \\
ELISA & Antibody & Blood & $86-100$ & $89-100$ & $60-180$ & $15-30$ \\
GICA & Antibody & Blood & $50-100$ & $90-100$ & $120-140$ \\
ddPCR & Virus mRNA & Respiratory swabs, saliva, sputum, BLF & $83-100$ & $48-100$ & $13-60$ \\
POC tests & Virus mRNA or & Respiratory swabs, saliva, sputum, BLF & $>95$ & 100 & {$[66,67]$} \\
& Antibody & & & & & {$[68]$} \\
\hline
\end{tabular}

the government to efficiently implement COVID-19 control. Taken together, we hereby propose the concept of a Cloud-based epidemic control system, which realizes smartphone-based POCT testing using microfluidic chips and updated tracking of confirmed cases. The COVID-19 management strategy composed of flexible detection methods, convenient information collection platforms and intelligent cloud management networks. We believe that this 


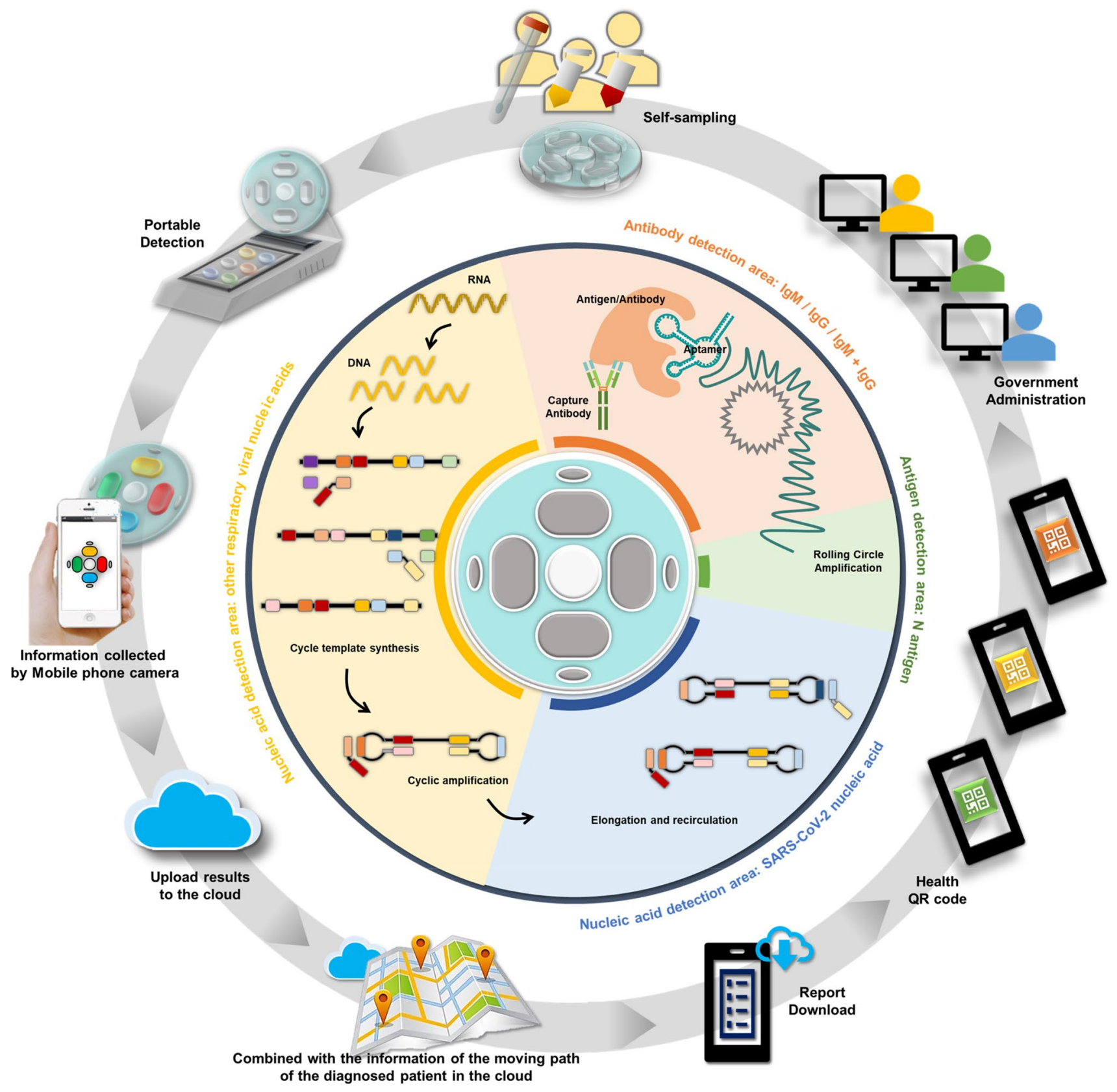

Fig. 6 Conceptual diagram of the combination of POCT detection and cloud-based intelligent medicine for SARS-CoV-2. The most central point is the integrated detection chip concept of nucleic acid, antigen, and antibody. The principle of nucleic acid detection (yellow and blue) is based on LAMP, and the principle of antigen and antibody detection (orange and green) is based on RCA after aptamer binding. The gray outer circle indicates the entire process from per-

advanced intelligent system will remarkably benefit the regional and global COVID-19 pandemic control (Fig. 6).

Author contributions FW, RY contributed to the conception of the study; CW, LH contributed significantly to analysis and manuscript sonal detection of remote diagnosis to government prevention and control. After the result is displayed by the color change of the chip, the input detection result of the camera of the smartphone can be uploaded to the cloud, and the personal health code is displayed in conjunction with the movement trajectory of the diagnosed patient. The gray outer circle indicates the entire process from personal detection of remote diagnosis to government prevention and control preparation; KY performed the data analyses and wrote the manuscript; The author(s) read and approved the final manuscript.

Funding This work was supported by the Fundamental Research Funds for the Central Universities (2042020kf1015), and the Improvement Project for Theranostic ability on Difficulty Miscellaneous disease (Tumor) of Zhongnan Hospital of Wuhan University 
(ZLYNXM202008). This work was also funded by Medical talented youth development project in Health Commission of Hubei Province.

\section{Compliance with ethical standards}

Conflict of interest The authors have declared that no competing interest exists.

\section{References}

1. Chen Y, Liu Q, Guo D (2020) Emerging coronaviruses: genome structure, replication, and pathogenesis. J Med Virol 92(4):418423. https://doi.org/10.1002/jmv.25681

2. Wu A, Peng Y, Huang B, Ding X, Wang X, Niu P, Meng J, Zhu Z, Zhang Z, Wang J, Sheng J, Quan L, Xia Z, Tan W, Cheng G, Jiang $T$ (2020) Genome composition and divergence of the novel coronavirus (2019-nCoV) originating in China. Cell Host Microbe. https://doi.org/10.1016/j.chom.2020.02.001

3. Xu X, Chen P, Wang J, Feng J, Zhou H, Li X, Zhong W, Hao $\mathrm{P}$ (2020) Evolution of the novel coronavirus from the ongoing wuhan outbreak and modeling of its spike protein for risk of human transmission. Sci China Life Sci. https://doi.org/10.1007/ s11427-020-1637-5

4. Zhang H, Kang Z, Gong H, Xu D, Wang J, Li Z, Cui X, Xiao J, Meng T, Zhou W, Liu J, Xu H (2020) The digestive system is a potential route of 2019-nCov infection: a bioinformatics analysis based on single-cell transcriptomes. J bioRxiv. https://doi. org/10.1101/2020.01.30.927806

5. Zhao Y, Zhao Z, Wang Y, Zhou Y, Ma Y, Zuo W (2020) Singlecell RNA expression profiling of ACE2, the receptor of SARSCoV-2. J bioRxiv. https://doi.org/10.1101/2020.01.26.919985

6. Xu Z, Shi L, Wang Y, Zhang J, Huang L, Zhang C, Liu S, Zhao P, Liu H, Zhu L, Tai Y, Bai C, Gao T, Song J, Xia P, Dong J, Zhao J, Wang FS (2020) Pathological findings of COVID-19 associated with acute respiratory distress syndrome. Lancet Respir Med 8(4):420-422. https://doi.org/10.1016/s2213-2600(20)30076-X

7. Sungnak W, Huang N, Becavin C, Berg M, Queen R, Litvinukova M, Talavera-Lopez C, Maatz H, Reichart D, Sampaziotis F, Worlock KB, Yoshida M, Barnes JL (2020) SARS-CoV-2 entry factors are highly expressed in nasal epithelial cells together with innate immune genes. Nat Med. https://doi.org/10.1038/s4159 1-020-0868-6

8. Li Z, Wu M, Yao J, Guo J, Liao X, Song S, Li J, Duan G, Zhou Y, Wu X, Zhou Z, Wang T, Hu M, Chen X, Fu Y, Lei C, Dong H, Xu C, Hu Y, Han M, Zhou Y, Jia H, Chen X, Yan J (2020) Caution on kidney dysfunctions of COVID-19 patients. J medRxiv. https ://doi.org/10.1101/2020.02.08.20021212

9. Diao B, Wang C, Wang R, Feng Z, Tan Y, Wang H, Wang C, Liu L, Liu Y, Liu Y, Wang G, Yuan Z, Ren L, Wu Y, Chen Y (2020) Human kidney is a target for novel severe acute respiratory syndrome coronavirus 2 (SARS-CoV-2) infection. J medRxiv. https ://doi.org/10.1101/2020.03.04.20031120

10. Chai X, Hu L, Zhang Y, Han W, Lu Z, Ke A, Zhou J, Shi G, Fang N, Fan J, Cai J, Fan J, Lan F (2020) Specific ACE2 expression in cholangiocytes may cause liver damage after 2019-nCoV infection. J bioRxiv. https://doi.org/10.1101/2020.02.03.931766

11. Hui H, Zhang Y, Yang X, Wang X, He B, Li L, Li H, Tian J, Chen $Y(2020)$ Clinical and radiographic features of cardiac injury in patients with 2019 novel coronavirus pneumonia. J medRxiv. https ://doi.org/10.1101/2020.02.24.20027052

12. Liu Y, Li J, liu D, Song H, Chen C, lv M, Pei X, Hu Z (2020) Clinical features and outcomes of 2019 novel coronavirus-infected patients with cardiac injury. J medRxiv. https://doi. org/10.1101/2020.03.11.20030957

13. Chen N, Zhou M, Dong X, Qu J, Gong F, Han Y, Qiu Y, Wang J, Liu Y, Wei Y, Xia Ja YuT, Zhang X, Zhang L (2020) Epidemiological and clinical characteristics of 99 cases of 2019 novel coronavirus pneumonia in Wuhan, China: a descriptive study. Lancet 395(10223):507-513. https://doi.org/10.1016/S0140 $-6736(20) 30211-7$

14. Virhammar J, Kumlien E, Fällmar D, Frithiof R, Jackmann S, Sköld MK, Kadir M, Frick J, Lindeberg J, Olivero-Reinius H, Ryttlefors M, Cunningham JL, Wikström J, Grabowska A, Bondeson K, Bergquist J, Zetterberg H, Rostami E (2020) Acute necrotizing encephalopathy with SARS-CoV-2 RNA confirmed in cerebrospinal fluid. Neurology. https://doi.org/10.1212/WNL.0000000000 010250

15. Domingues RB, Mendes-Correa MC, de Moura Leite FBV, Sabino EC, Salarini DZ, Claro I, Santos DW, de Jesus JG, Ferreira NE, Romano CM, Soares CAS (2020) First case of SARS-COV-2 sequencing in cerebrospinal fluid of a patient with suspected demyelinating disease. J Neurol. https://doi.org/10.1007/s0041 5-020-09996-w

16. Al Saiegh F, Ghosh R, Leibold A, Avery MB, Schmidt RF, Theofanis T, Mouchtouris N, Philipp L, Peiper SC, Wang Z-X, Rincon F, Tjoumakaris SI, Jabbour P, Rosenwasser RH, Gooch MR (2020) Status of SARS-CoV-2 in cerebrospinal fluid of patients with COVID-19 and stroke. J Neurol Neurosurg Psychiatry 91(8):846-848. https://doi.org/10.1136/jnnp-2020-323522

17. Mao L, Jin H, Wang M, Hu Y, Chen S, He Q, Chang J, Hong C, Zhou Y, Wang D, Miao X, Li Y, Hu B (2020) Neurologic manifestations of hospitalized patients with coronavirus disease 2019 in Wuhan, China. JAMA Neurol. https://doi.org/10.1001/jaman eurol.2020.1127

18. Cao X (2020) COVID-19: immunopathology and its implications for therapy. Nat Rev Immunol 20(5):269-270. https://doi. org/10.1038/s41577-020-0308-3

19. Yao XH, He ZC, Li TY, Zhang HR, Wang Y, Mou H, Guo Q, Yu SC, Ding Y, Liu X, Ping YF, Bian XW (2020) Pathological evidence for residual SARS-CoV-2 in pulmonary tissues of a ready-for-discharge patient. Cell Res. https://doi.org/10.1038/ s41422-020-0318-5

20. Kadkhoda K (2020) COVID-19: an immunopathological view. Msphere. https://doi.org/10.1128/mSphere.00344-20

21. Channappanavar R, Perlman S (2017) Pathogenic human coronavirus infections: causes and consequences of cytokine storm and immunopathology. Semin Immunopathol 39(5):529-539. https:// doi.org/10.1007/s00281-017-0629-x

22. Pierini S, Incampo E, Bokor D, Dadone V, Ornaghi M, Zanini F, Gentile F, Mancarella S (2020) Coagulopathy in COVID-19: pathophysiology. G Ital Cardiol (Rome) 21(7):483-488. https:// doi.org/10.1714/3386.33633

23. Lowe CF, Matic N, Ritchie G, Lawson T, Stefanovic A, Champagne S, Leung V, Romney MG (2020) Detection of low levels of SARS-CoV-2 RNA from nasopharyngeal swabs using three commercial molecular assays. J Clin Virol 128:104387. https:// doi.org/10.1016/j.jcv.2020.104387

24. Yang Y, Yang M, Shen C, Wang F, Yuan J, Li J, Zhang M, Wang Z, Xing L, Wei J, Peng L, Wong G, Zheng H, Liao M, Feng K, Li J, Yang Q, Zhao J, Zhang Z, Liu L, Liu Y (2020) Evaluating the accuracy of different respiratory specimens in the laboratory diagnosis and monitoring the viral shedding of 2019-nCoV infections. J medRxiv. https://doi.org/10.1101/2020.02.11.20021493\%

25. Zou L, Ruan F, Huang M, Liang L, Huang H, Hong Z, Yu J, Kang M, Song Y, Xia J, Guo Q, Song T, He J, Yen HL, Peiris M, Wu J (2020) SARS-CoV-2 viral load in upper respiratory specimens of infected patients. N Engl J Med. https://doi.org/10.1056/NEJMc 2001737 
26. Chen LaZ Jiajia Peng Jinfeng, Li Xiaoshuang, Deng Xuliang, Geng Zhi, Shen Zhenyu, Guo Fengyuan, Zhang Qianwen, Jin Yang, Wang Lin, Wang Songlin 2019 Detection of 2019-nCoV in saliva and characterization of oral symptoms in COVID19 patients https://ssrn.com/abstract=3557140 or https://doi. org/10.2139/ssrn.3557140.

27. To KK, Tsang OT, Leung WS, Tam AR, Wu TC, Lung DC, Yip CC, Cai JP, Chan JM, Chik TS, Lau DP, Choi CY, Chen LL, Chan WM, Chan KH, Ip JD, Ng AC, Poon RW, Luo CT, Cheng VC, Chan JF, Hung IF, Chen Z, Chen H, Yuen KY (2020) Temporal profiles of viral load in posterior oropharyngeal saliva samples and serum antibody responses during infection by SARS-CoV-2: an observational cohort study. Lancet Infect Dis 20(5):565-574. https://doi.org/10.1016/s1473-3099(20)30196 $-1$

28. Chen JH-K, Yip CC-Y, Poon RW-S, Chan K-H, Cheng VC-C, Hung IF-N, Chan JF-W, Yuen K-Y, To KK-W (2020) Evaluating the use of posterior oropharyngeal saliva in a point-of-care assay for the detection of SARS-CoV-2. Emerg Microbes Infect 9(1):1356-1359. https://doi.org/10.1080/22221751.2020.1775133

29. Long QX, Liu BZ, Deng HJ, Wu GC, Deng K, Chen YK, Liao P, Qiu JF, Lin Y, Cai XF, Wang DQ, Hu Y, Ren JH, Tang N, Xu YY, Yu LH, Mo Z, Gong F, Zhang XL, Tian WG, Hu L, Zhang XX, Xiang JL, Du HX, Liu HW, Lang CH, Luo XH, Wu SB, Cui XP, Zhou Z, Zhu MM, Wang J, Xue CJ, Li XF, Wang L, Li ZJ, Wang K, Niu CC, Yang QJ, Tang XJ, Zhang Y, Liu XM, Li JJ, Zhang DC, Zhang F, Liu P, Yuan J, Li Q, Hu JL, Chen J, Huang AL (2020) Antibody responses to SARS-CoV-2 in patients with COVID-19. Nat Med. https://doi.org/10.1038/s41591-020-0897-1

30. Okba NMA, Müller MA, Li W, Wang C, GeurtsvanKessel CH, Corman VM, Lamers MM, Sikkema RS, de Bruin E, Chandler FD, Yazdanpanah Y, Le Hingrat Q, Descamps D, Houhou-Fidouh N, Reusken C, Bosch BJ, Drosten C, Koopmans MPG, Haagmans BL (2020) Severe acute respiratory syndrome coronavirus 2 -specific antibody responses in coronavirus disease patients. Emerg Infect Dis 26(7):1478-1488. https://doi.org/10.3201/eid26 07.200841

31. Burbelo PD, Riedo FX, Morishima C, Rawlings S, Smith D, Das S, Strich JR, Chertow DS, Davey RT, Cohen JI (2020) Sensitivity in detection of antibodies to nucleocapsid and spike proteins of severe acute respiratory syndrome coronavirus 2 in patients with coronavirus disease 2019. J Infect Dis 222(2):206-213. https:// doi.org/10.1093/infdis/jiaa273

32. Zhao J, Yuan Q, Wang H, Liu W, Liao X, Su Y, Wang X, Yuan J, Li T, Li J, Qian S, Hong C, Wang F, Liu Y, Wang Z, He Q, Li Z, He B, Zhang T, Fu Y, Ge S, Liu L, Zhang J, Xia N, Zhang Z (2020) Antibody responses to SARS-CoV-2 in patients of novel coronavirus disease 2019. Clin Infect Dis. https://doi.org/10.1093/ $\mathrm{cid} / \mathrm{ciaa} 344$

33. Lisboa Bastos M, Tavaziva G, Abidi SK, Campbell JR, Haraoui LP, Johnston JC, Lan Z, Law S, MacLean E, Trajman A, Menzies D, Benedetti A, Ahmad Khan F (2020) Diagnostic accuracy of serological tests for covid-19: systematic review and metaanalysis. BMJ (Clinical research ed) 370:m2516. https://doi. org/10.1136/bmj.m2516

34. Guan W-j, Ni Z-y, Hu Y, Liang W-h, Ou C-q, He J-x, Liu L, Shan H, Lei C-1, Hui DSC, Du B, Li L-j, Zeng G, Yuen K-Y, Chen R-c, Tang C-1, Wang T, Chen P-y, Xiang J, Li S-y, Wang J-1, Liang Z-j, Peng Y-x, Wei L, Liu Y, Hu Y-h, Peng P, Wang J-m, Liu J-y, Chen Z, Li G, Zheng Z-j, Qiu S-q, Luo J, Ye C-j, Zhu S-y, Zhong $\mathrm{N}$-s (2020) Clinical characteristics of coronavirus disease 2019 in China. N Engl J Med 382(18):1708-1720. https://doi.org/10.1056/ NEJMoa2002032

35. Wang D, Hu B, Hu C, Zhu F, Liu X, Zhang J, Wang B, Xiang H, Cheng Z, Xiong Y, Zhao Y, Li Y, Wang X, Peng Z (2020) Clinical characteristics of 138 hospitalized patients with 2019 novel coronavirus-infected pneumonia in Wuhan, China. JAMA. https ://doi.org/10.1001/jama.2020.1585

36. Huang C, Wang Y, Li X, Ren L, Zhao J, Hu Y, Zhang L, Fan G, Xu J, Gu X, Cheng Z, Yu T, Xia J, Wei Y, Wu W, Xie X, Yin W, Li H, Liu M, Xiao Y, Gao H, Guo L, Xie J, Wang G, Jiang R, Gao Z, Jin Q, Wang J, Cao B (2020) Clinical features of patients infected with 2019 novel coronavirus in Wuhan, China. Lancet (London, England) 395(10223):497-506. https://doi.org/10.1016/ s0140-6736(20)30183-5

37. Fang Y, Zhang H, Xu Y, Xie J, Pang P, Ji W (2020) CT manifestations of two cases of 2019 novel coronavirus (2019-nCoV) pneumonia. Radiology 295(1):208-209. https://doi.org/10.1148/ radiol.2020200280

38. Zhou F, Yu T, Du R, Fan G, Liu Y, Liu Z, Xiang J, Wang Y, Song B, Gu X, Guan L, Wei Y, Li H, Wu X, Xu J, Tu S, Zhang Y, Chen $\mathrm{H}$, Cao B (2020) Clinical course and risk factors for mortality of adult inpatients with COVID-19 in Wuhan, China: a retrospective cohort study. Lancet (London, England) 395(10229):1054-1062. https://doi.org/10.1016/s0140-6736(20)30566-3

39. Liu J, Liu Y, Xiang P, Pu L, Xiong H, Li C, Zhang M, Tan J, Xu Y, Song R, Song M, Wang L, Zhang W, Han B, Yang L, Wang X, Zhou G, Zhang T, Li B, Wang Y, Chen Z, Wang X (2020) Neutrophil-to-lymphocyte ratio predicts severe illness patients with 2019 novel coronavirus in the early stage. J medRxiv. https ://doi.org/10.1101/2020.02.10.20021584

40. Guan W-j, Liang W-h, Zhao Y, Liang H-r, Chen Z-s, Li Y-m, Liu X-q, Chen R-c, Tang C-1, Wang T, Ou C-q, Li L, Chen P-y, Sang L, Wang W, Li J-f, Li C-c, Ou L-m, Cheng B, Xiong S, Ni Z-y, Hu Y, Xiang J, Liu L, Shan H, Lei C-1, Peng Y-x, Wei L, Liu Y, Hu Y-h, Peng P, Wang J-m, Liu J-y, Chen Z, Li G, Zheng Z-j, Qiu S-q, Luo J, Ye C-j, Zhu S-y, Cheng L-1, Ye F, Li S-y, Zheng J-p, Zhang N-f, Zhong N-s, He J-x (2020) Comorbidity and its impact on 1590 patients with COVID-19 in China: a nationwide analysis. J medRxiv. https://doi.org/10.1101/2020.02.25.20027664\%

41. Liu PP, Blet A, Smyth D, Li H (2020) The science underlying COVID-19: implications for the cardiovascular system. Circulation. https://doi.org/10.1161/circulationaha.120.047549

42. Chen X, Hu W, Ling J, Mo P, Zhang Y, Jiang Q, Ma Z, Cao Q, Deng L, Song S, Zheng R, Gao S, Ke H, Gui X, Lundkvist $\AA$, Li J, Lindahl JF, Xiong Y (2020) Hypertension and diabetes delay the viral clearance in COVID-19 patients. J medRxiv. https://doi. org/10.1101/2020.03.22.20040774

43. Xie J, Tong Z, Guan X, Du B, Qiu H (2020) Clinical characteristics of patients who died of coronavirus disease 2019 in China. JAMA Netw Open 3(4):e205619. https://doi.org/10.1001/jaman etworkopen.2020.5619

44. Zhu L, She ZG, Cheng X, Qin JJ, Zhang XJ, Cai J, Lei F, Wang H, Xie J, Wang W, Li H, Zhang P, Song X, Chen X, Xiang M, Zhang C, Bai L, Xiang D, Chen MM, Liu Y, Yan Y, Liu M, Mao W, Zou J, Liu L, Chen G, Luo P, Xiao B, Zhang C, Zhang Z, Lu Z, Wang J, Lu H, Xia X, Wang D, Liao X, Peng G, Ye P, Yang J, Yuan Y, Huang X, Guo J, Zhang BH, Li H (2020) Association of blood glucose control and outcomes in patients with COVID-19 and pre-existing type 2 diabetes. Cell Metab. https://doi.org/10.1016/j. cmet.2020.04.021

45. Liang W, Guan W, Chen R, Wang W, Li J, Xu K, Li C, Ai Q, Lu W, Liang H, Li S, He J (2020) Cancer patients in SARSCoV-2 infection: a nationwide analysis in China. Lancet Oncol 21(3):335-337. https://doi.org/10.1016/s1470-2045(20)30096-6

46. Zhao N, Shi J, Zeng L, Yang S (2020) Clinical characteristics and coping strategies of neoplasms with 2019 novel coronavirus infection. Chin J Lung Cancer 23(4):261-266. https://doi. org/10.3779/j.issn.1009-3419.2020.102.15

47. Zhang B, Zhou X, Zhu C, Feng F, Qiu Y, Feng J, Jia Q, Song Q, Zhu B, Wang J (2020) Immune phenotyping based on neutrophil-to-lymphocyte ratio and $\mathrm{IgG}$ predicts disease severity and 
outcome for patients with COVID-19. J medRxiv. https://doi. org/10.1101/2020.03.12.20035048\%

48. Wan S, Yi Q, Fan S, Lv J, Zhang X, Guo L, Lang C, Xiao Q, Xiao K, Yi Z, Qiang M, Xiang J, Zhang B, Chen Y (2020) Characteristics of lymphocyte subsets and cytokines in peripheral blood of 123 hospitalized patients with 2019 novel coronavirus pneumonia (NCP). J medRxiv. https://doi.org/10.1101/2020.02.10.20021832

49. Wang M, Wu Q, Xu W, Qiao B, Wang J, Zheng H, Jiang S, Mei J, Wu Z, Deng Y, Zhou F, Wu W, Zhang Y, Lv Z, Huang J, Guo X, Feng L, Xia Z, Li D, Xu Z, Liu T, Zhang P, Tong Y, Li Y (2020) Clinical diagnosis of 8274 samples with 2019-novel coronavirus in Wuhan. J medRxiv. https://doi.org/10.1101/2020.02.12.20022 327

50. Bohn MK, Lippi G, Horvath A, Sethi S, Koch D, Ferrari M, Wang C-B, Mancini N, Steele S, Adeli K (2020) Molecular, serological, and biochemical diagnosis and monitoring of COVID-19: IFCC taskforce evaluation of the latest evidence. Clin Chem Lab Med 58(7):1037-1052. https://doi.org/10.1515/cclm-2020-0722

51. Lippi G, Plebani M (2020) Laboratory abnormalities in patients with COVID-2019 infection. Clin Chem Lab Med 58(7):11311134. https://doi.org/10.1515/cclm-2020-0198

52. Zheng Y, Huang Z, Ying G, Zhang X, Ye W, Hu Z, Hu C, Wei H, Zeng Y, Chi Y, Cheng C, Lin F, Lu H, Xiao L, Song Y, Wang C, Yi Y, Dong L (2020) Comparative study of the lymphocyte change between COVID-19 and non-COVID-19 pneumonia cases suggesting uncontrolled inflammation might not be the main reason of tissue injury. J medRxiv. https://doi. org/10.1101/2020.02.19.20024885

53. Zheng S, Fan J, Yu F, Feng B, Lou B, Zou Q, Xie G, Lin S, Wang R, Yang X, Chen W, Wang Q, Zhang D, Liu Y, Gong R, Ma Z, Lu S, Xiao Y, Gu Y, Zhang J, Yao H, Xu K, Lu X, Wei G, Zhou J, Fang Q, Cai H, Qiu Y, Sheng J, Chen Y, Liang T (2020) Viral load dynamics and disease severity in patients infected with SARS-CoV-2 in Zhejiang province, China, January-March 2020: retrospective cohort study. BMJ (Clinical research ed) 369:m1443. https://doi.org/10.1136/bmj.m1443

54. Wang M, Fu A, Hu B, Tong Y, Liu R, Gu J, Liu J, Jiang W, Shen G, Zhao W, Men D, Yu L, Deng Z, Li Y, Liu T (2020) Nanopore target sequencing for accurate and comprehensive detection of SARS-CoV-2 and other respiratory viruses. J medRxiv. https:// doi.org/10.1101/2020.03.04.20029538

55. Su W, Gao X, Jiang L, Qin J (2015) Microfluidic platform towards point-of-care diagnostics in infectious diseases. J Chromatogr A 1377:13-26. https://doi.org/10.1016/j.chroma.2014.12.041

56. Rodriguez-Manzano J, Karymov MA, Begolo S, Selck DA, Zhukov DV, Jue E, Ismagilov RF (2016) Reading out single-molecule digital RNA and DNA isothermal amplification in nanoliter volumes with unmodified camera phones. ACS Nano 10(3):31023113. https://doi.org/10.1021/acsnano.5b07338

57. Liu B, Zhang D, Ni H, Wang D, Jiang L, Fu D, Han X, Zhang C, Chen H, Gu Z, Zhao X (2018) Multiplex analysis on a single porous hydrogel bead with encoded SERS nanotags. ACS Appl Mater Interfaces 10(1):21-26. https://doi.org/10.1021/acsam i.7b14942

58. Smithgall MC, Scherberkova I, Whittier S, Green DA (2020) Comparison of cepheid Xpert Xpress and abbott ID now to roche cobas for the rapid detection of SARS-CoV-2. J Clin Virol 128:104428. https://doi.org/10.1016/j.jcv.2020.104428

59. Jayamohan H, Lambert CJ, Sant HJ, Jafek A, Patel D, Feng H, Beeman M, Mahmood T, Nze U, Gale BK (2020) SARS-CoV-2 pandemic: a review of molecular diagnostic tools including sample collection and commercial response with associated advantages and limitations. Anal Bioanal Chem. https://doi. org/10.1007/s00216-020-02958-1

60. Hu X, Zhu L, Luo Y, Zhao Q, Tan C, Chen X, Zhang H, Hu X, Lu L, Xiao Y, Huang S, He Y, Sim Xiu Ling J, Su S, Wang
F, Peng Y, Wang J, Guo Y, Zhong T (2020) Evaluation of the clinical performance of single-, dual-, and triple-target SARSCoV-2 RT-qPCR methods. Clin Chim Acta 511:143-148. https ://doi.org/10.1016/j.cca.2020.10.008

61. Javalkote VS, Kancharla N, Bhadra B, Shukla M, Soni B, Goodin M, Bandyopadhyay A, Dasgupta S (2020) CRISPR-based assays for rapid detection of SARS-CoV-2. Methods (San Diego, Calif). https://doi.org/10.1016/j.ymeth.2020.10.003

62. Huang W, Yu L, Wen D, Wei D, Sun Y, Zhao H, Ye Y, Chen W, Zhu Y, Wang L, Wang L, Wu W, Zhao Q, Xu Y, Gu D, Nie G, Zhu D, Guo Z, Ma X, Niu L, Huang Y, Liu Y, Peng B, Zhang R, Zhang X, Li D, Liu Y, Yang G, Liu L, Zhou Y, Wang Y, Hou T, Gao Q, Li W, Chen S, Hu X, Han M, Zheng H, Weng J, Cai Z, Zhang X, Song F, Zhao G, Wang J (2020) A CRISPRCas12a-based specific enhancer for more sensitive detection of SARS-CoV-2 infection. EBioMedicine 61:103036. https://doi. org/10.1016/j.ebiom.2020.103036

63. Brandsma E, Verhagen H, van de Laar TJW, Claas ECJ, Cornelissen M, van den Akker E (2020) Rapid, sensitive and specific SARS coronavirus-2 detection: a multi-center comparison between standard qRT-PCR and CRISPR based DETECTR. J Infect Dis. https://doi.org/10.1093/infdis/jiaa641

64. Dhamad AE, Abdal Rhida MA (2020) COVID-19: molecular and serological detection methods. PeerJ 8:e10180. https://doi. org/10.7717/peerj. 10180

65. Isho B, Abe KT, Zuo M, Jamal AJ, Rathod B, Wang JH, Li Z, Chao G, Rojas OL, Bang YM, Pu A, Christie-Holmes N, Gervais C, Ceccarelli D, Samavarchi-Tehrani P, Guvenc F, Budylowski P, Li A, Paterson A, Yue FY, Marin LM, Caldwell L, Wrana JL, Colwill K, Sicheri F, Mubareka S, Gray-Owen SD, Drews SJ, Siqueira WL, Barrios-Rodiles M, Ostrowski M, Rini JM, Durocher Y, McGeer AJ, Gommerman JL, Gingras AC (2020) Persistence of serum and saliva antibody responses to SARS-CoV-2 spike antigens in COVID-19 patients. Sci Immunol. https://doi.org/10.1126/sciimmunol.abe5511

66. Suo T, Liu X, Feng J, Guo M, Hu W, Guo D, Ullah H, Yang Y, Zhang Q, Wang X, Sajid M, Huang Z, Deng L, Chen T, Liu F, Xu K, Liu Y, Zhang Q, Liu Y, Xiong Y, Chen G, Lan K, Chen Y (2020) ddPCR: a more accurate tool for SARS-CoV-2 detection in low viral load specimens. Emerg Microbes Infect 9(1):1259-1268. https://doi.org/10.1080/22221751.2020.17726 78

67. Falzone L, Musso N, Gattuso G, Bongiorno D, Palermo CI, Scalia G, Libra M, Stefani S (2020) Sensitivity assessment of droplet digital PCR for SARS-CoV-2 detection. Int J Mol Med 46(3):957964. https://doi.org/10.3892/ijmm.2020.4673

68. Kile Green SG, Philip Turner, Thomas Fanshawe, Joy Allen (2020) Molecular and antibody point-of-care tests to support the screening, diagnosis and monitoring of COVID-19. . https://www. cebm.net/covid-19/molecular-and-antibody-point-of-care-tests-tosupport-the-screening-diagnosis-and-monitoring-of-covid-19.

69. Tayarani NM (2020) Applications of artificial intelligence in battling against Covid-19: a literature review. Chaos solitons fractals. https://doi.org/10.1016/j.chaos.2020.110338

70. Rasheed J, Jamil A, Hameed AA, Aftab U, Aftab J, Shah SA, Draheim D (2020) A survey on artificial intelligence approaches in supporting frontline workers and decision makers for COVID19 pandemic. Chaos Solitons Fractals. https://doi.org/10.1016/j. chaos.2020.110337

71. Boškoski I, Gallo C, Wallace MB, Costamagna G (2020) COVID19 pandemic and personal protective equipment shortage: protective efficacy comparing masks and scientific methods for respirator reuse. Gastrointest Endosc 92(3):519-523. https://doi. org/10.1016/j.gie.2020.04.048

72. Jia Q, Guo Y, Wang G, Barnes SJ (2020) Big data analytics in the fight against major public health incidents (Including COVID-19): 
a conceptual framework. Int J Environ Res Public Health. https:// doi.org/10.3390/ijerph17176161

73. Radanliev P, De Roure D, Walton R, Van Kleek M, Montalvo RM, Santos O, Maddox L, Cannady S (2020) COVID-19 what have we learned? The rise of social machines and connected devices in pandemic management following the concepts of predictive, preventive and personalized medicine. EPMA J 11(3):311-332. https://doi.org/10.1007/s13167-020-00218-x

74. Agbehadji IE, Awuzie BO, Ngowi AB, Millham RC (2020) Review of big data analytics, artificial intelligence and natureinspired computing models towards accurate detection of COVID19 pandemic cases and contact tracing. Int J Environ Res Public Health. https://doi.org/10.3390/ijerph17155330
75. Mehraeen M, Dadkhah M, Mehraeen A (2020) Investigating the capabilities of information technologies to support policymaking in COVID-19 crisis management; a systematic review and expert opinions. Eur J Clin Invest. https://doi.org/10.1111/eci.13391

Publisher's Note Springer Nature remains neutral with regard to jurisdictional claims in published maps and institutional affiliations. 